\title{
System Diversification for Livestock Nutritional Security through Biomass Yield and Nutritive Value of Fodder Legume Calopogonium mucunoides under Cocus nucifera/Psidium guajava Based Hortipasture System
}

\author{
V.S. Mynavathi", Karu. Pasupathi and C. Valli \\ Department of Agronomy, AICRP on Agroforestry, Institute of Animal Nutrition, Tamil Nadu \\ Veterinary and Animal Sciences University, Kattupakkam-603203, Tamil Nadu, India \\ *Corresponding author
}

\section{A B S T R A C T}

\section{Keywords}

Fodder legume,

Nutritive value,

Proximate

composition and

Digestibility.

Article Info

Accepted:

04 June 2017

Available Online:

10 August 2017
Green fodder supplementation is the best way to reduce the cost of production in livestock farming. The expenditure on concentrate feed will be curtail by feeding of legume fodder. Urbanization reduces the land area for fodder production and also the failure in monsoon urges the farmers to go for fodder production under agroforestry models. Calopogonium mucunoides is a fodder legume with high quality protein and grows fast and remain productive during dry seasons. It also improves the soil nitrogen by fixing and makes the soil fertile (Mc Donald et al., 2011). Hence, the present experiment was conducted to study the suitability of Calopogonium mucunoides as understorey of Cocus nucifera I Psidium guajava based hortipasture system and assesing its nutritive value in goats. Experiment was conducted at Institute of Animal Nutrition, Kattupakkam. In the existing hortipasture, interspaces between Cocus nucifera / Psidium guajava in degraded wasteland was taken for the cultivation of Calapagonium mucunoides as per the standard package of practices and harvested twice to document the yield. The Mean biomass yield (MT/ha) of Calopogonium mucunoides as sole crop vs understorey of Psidium guajava and Cocus nucifera was recorded. Samples of Calopogonium mucunoides were also estimated for their proximate principles as per AOAC (2000). The digestibility of Calopogonium mucunoides was assessed in 6 Kanni goats by difference method. Based on the findings, it is concluded that higher biomass yield was recorded with the understorey of Cocus nucifera compared to the understorey of Psidium guajava could be due to the optimum sunlight. Therefore, there is potential to improve the Cocus nucifera based hortipasture by incorporating Calopogonium mисипoides as fodder cum legume cover crop thus improves the soil fertility.

\section{Introduction}

Agroforestry is a land use option that increase livelihood security and reduce vulnerability to climate change. Hortipasture is one among the agroforestry systems which involves integration of fruit trees with pasture. Green fodder supplementation is the best way to reduce the cost of production in livestock farming. The expenditure on concentrate feed will be curtail by feeding of legume fodder. Urbanization reduces the land area for fodder production and also the failure in monsoon urges the farmers to go for fodder production under agroforestry models. Hortipasture based agroforestry model has gained popularity among farmers for its ability to contribute economically. Calopogonium mucunoides is a 
fodder legume with high quality protein and grows fast and remain productive during dry seasons. It also improves the soil nitrogen by fixing and makes the soil fertile (Mc Donald et al., 2011). Hence, the present experiment was conducted to study the biomass yield and proximate composition of Calopogonium mucunoides grown under Cocus nucifera / Psidium guajava based hortipasture system and to assess the feeding value of Calopogonium mucunoides in goats.

\section{Materials and Methods}

Field experiment was conducted during 2015 at Institute of Animal Nutrition, Kattupakkam as a part of the All India Co-ordinated Research Project on Agroforestry. The soil of the experiment site is calcareous in texture. In the existing hortipasture, interspaces between Cocus nucifera/Psidium guajava in degraded wasteland was used for the study. Land area under Cocus nuciferalPsidium guajava was ploughed and the land was prepared for sowing the fodder. After land preparation application of organic manure was done as per the standard package of practices. Calapagonium mucunoides seeds were sown by broadcasting method following seed treatment (viz. overnight soaking in water), under Cocus nucifera (10 cents) and Psidium guajava (10 cents). The crop was harvested twice. The Mean biomass yield (MT/ha) of Calopogonium mucunoides as sole crop vs. understorey of Psidium guajava and Cocus nucifera was recorded. Samples of Calopogonium mucunoides were also estimated for their proximate principles as per AOAC (2000). The digestibility of Calopogonium mucunoides was assessed in Six Kanni goats by difference method since leguminous fodder could not be fed as sole feed to ruminants. Cumbu Napier hybrid grass was taken as standard roughage. The first phase of the trial was conducted wherein Cumbu Napier grass was offered as sole feed. First 10 days was adaptation period and then the subsequent six days was collection period, wherein the feed offered, residue left, faeces voided were recorded and representative samples were taken for analysis. In the second phase of the trial one third of the dry matter intake was offered through Calopogonium mucunoides leaves. As in first phase, after 10 days adaptation period, six days collection was made and digestibility of Calopogonium mucunoides was estimated by difference method.

\section{Results and Discussion}

Calopogonium mucunoides was integrated under both Cocus nucifera and Psidium guajava. Biomass yield documented under Cocus nucifera revealed 9.80 MT fresh biomass/ha /annum under the influence of shade vs. 6.30 MT fresh biomass/ha /annum under direct sunlight. Biomass yield documented under Psidium guajava revealed 4.06 MT fresh biomass/ha /annum under the influence of shade $v s$. 6.30 MT fresh biomass/ha /annum under direct sunlight. The result of the experiment is presented in figure 1.

Biomass yield of Calopogonium mucunoides as a sole crop was highest. The crop yield was better under Cocus nucifera compared to that under Psidium gujava. The first harvest yield was higher than second harvest yield irrespective of whether the crop was cultivated as sole or understorey Cocus nucifera or Psidium guajava.

The crude protein of Calopogonium mucunoides as understorey Psidium guajava was the lowest in both the harvests.

Dense shade understorey Psidium guajava could have been the attributing factor. The crude fibre content was lowest when grown as a sole crop. This was evident in both the harvests as shown in table 1 . 
Fig.1 Mean biomass yield (MT/ha) of Calopogonium mucunoides

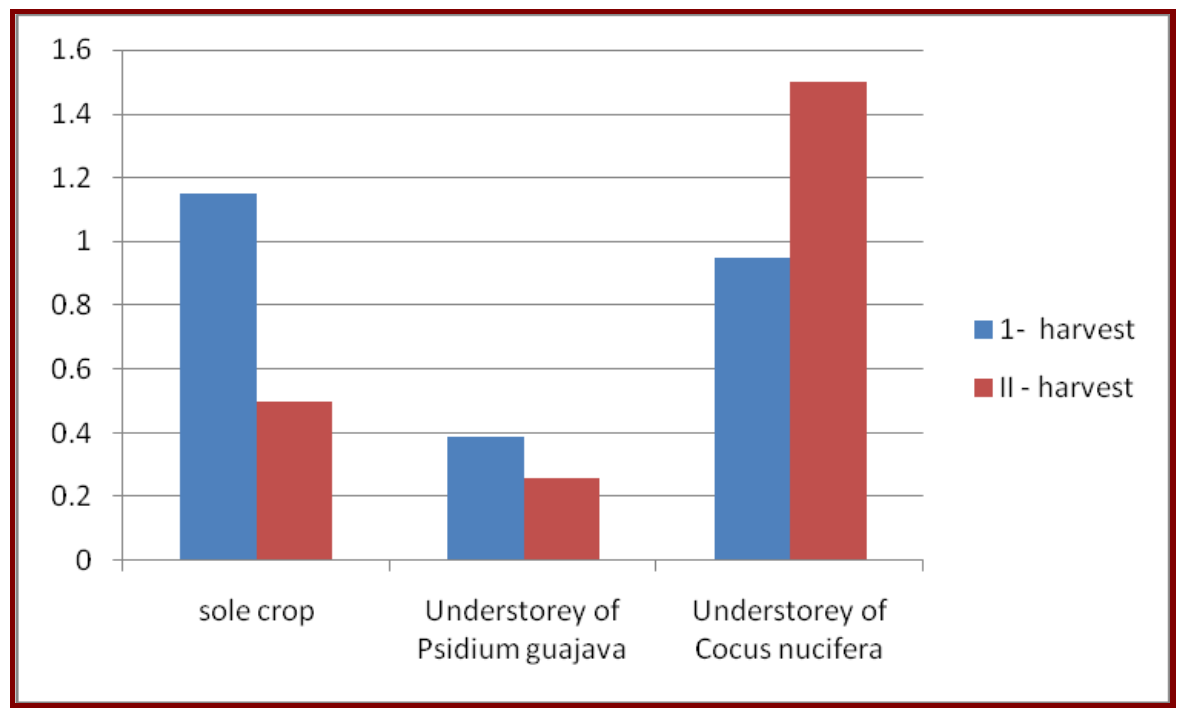

Table.1 Proximate composition (\%DMB) of Calopogonium mucunoides as sole crop vs. understorey of Psidium guajava / Cocus nucifera

\begin{tabular}{|c|l|c|c|c|c|c|c|}
\hline Harvest & Sole vs. Shade & Moisture & $\begin{array}{l}\text { Crude } \\
\text { Protein }\end{array}$ & $\begin{array}{l}\text { Ether } \\
\text { extract }\end{array}$ & $\begin{array}{l}\text { Crude } \\
\text { Fibre }\end{array}$ & $\begin{array}{l}\text { Total } \\
\text { ash }\end{array}$ & NFE \\
\hline \multirow{2}{*}{ I } & Sole & 74.47 & 17.21 & 2.65 & 34.6 & 10.35 & 35.19 \\
\cline { 2 - 8 } & $\begin{array}{l}\text { Under } \\
\text { nucifera }\end{array}$ & 76.54 & 17.42 & 2.99 & 44.12 & 12.4 & 23.07 \\
\cline { 2 - 8 } & $\begin{array}{l}\text { Under } \\
\text { Psidium guajava }\end{array}$ & 82.45 & 14.28 & 1.92 & 43.45 & 10.58 & 29.77 \\
\hline \multirow{2}{*}{ II } & Sole Cocus & 73.28 & 18.1 & 2.26 & 36.9 & 10.1 & 32.64 \\
\cline { 2 - 8 } & $\begin{array}{l}\text { Under } \\
\text { nucifera }\end{array}$ & 75.43 & 18.61 & 2.37 & 42.47 & 11.02 & 25.53 \\
\cline { 2 - 8 } & $\begin{array}{l}\text { Under } \\
\text { Psidium guajava }\end{array}$ & 82.21 & 15.74 & 2.13 & 42.4 & 10.97 & 28.76 \\
\hline
\end{tabular}

Table.2 Digestibility coefficient of Calopogonium mucunoides (\%DMB)

\begin{tabular}{|l|l|}
\hline Nutrient & Digestibility coefficient (\%) \\
\hline Dry matter & $81.32 \pm 2.07$ \\
\hline Crude protein & $68.27 \pm 6.87$ \\
\hline Ether extract & $74.23 \pm 3.76$ \\
\hline Crude fibre & $63.51 \pm 3.61$ \\
\hline Nitrogen free extract & $86.89 \pm 2.11$ \\
\hline Organic matter & $80.03 \pm 2.37$ \\
\hline
\end{tabular}


The results clearly indicate that higher biomass yield was recorded under optimum sunlight (under Cocus nucifera) and enough light supports the crop to uptake the nutrients from the soil this leads to higher proximate composition.

\section{Digestibility of Calopogonium mucunoides in small ruminants}

The digestibility trial results revealed that the nutrients present in the Calopogonium mucunoides was better digested in goats with higher digestibility coefficient (Table 2 ).

From the study, it is concluded that higher biomass yield was recorded with the understorey of Cocus nucifera compared to the understorey of Psidium guajava could be due to the optimum sunlight. Therefore, there is potential to improve the Cocus nucifera based hortipasture by incorporating Calopogonium mucunoides as fodder cum legume cover crop thus improves the soil fertility.

\section{References}

AOAC 1990. Official and Tentative Methods of Analysis, (12th Ed.) Association of Official Analytical Chemists, Washington, D.C., 1094 p.

McDonald, P., Edwards, R. A., Greenhalgh, J. F. D., Morgan, C. A., Sinclair, L. A., Wilkinson, R. G. 2011. Grass and forage crops. In: Animal Nutrion, 481498. Aschford Colour Press, Gosport.

\section{How to cite this article:}

Mynavathi, V.S., Karu. Pasupathi and Valli, C. 2017. System Diversification for Livestock Nutritional Security through Biomass Yield and Nutritive Value of Fodder Legume Calopogonium mucunoides under Cocus nuciferalPsidium guajava Based Hortipasture System. Int.J.Curr.Microbiol.App.Sci. 6(8): 133-136. doi: https://doi.org/10.20546/ijcmas.2017.608.018 